\title{
Ecosystems and sustainable metabolisms
}

\author{
J. J. Galan Vivas ${ }^{1}$, G. Peiro Frias ${ }^{2}$ \& A. Fernandez Morote ${ }^{3}$ \\ ${ }^{1}$ Department of Architecture, Aalto University, Finland \\ ${ }^{2}$ Azimut Consulting, Spain \\ ${ }^{3}$ Spain
}

\begin{abstract}
The Strategic Plan for the Calderona Mountain Range (Valencia, Spain) covers an area of $200 \mathrm{~km}^{2}$ including 5 municipalities located at the northern edge of Valencia's Metropolitan Area. The Plan deals with a wide diversity of aspects, being ecology and sustainable development their common denominators.

Thus, the analysis of the different territorial layers (forestry, agriculture, natural environment, urban planning, landscape, heritage, tourism and public use, mobility and infrastructures, and economic activity) was developed from an ecological and sustainability focused point of view which is afterwards extended in the definition of regional strategies and in a set of ten thematic plans and eighteen pilot projects.

In particular, sustainability, the structural role of ecology and the effective enhancement of the different existing and potential ecosystems, permeate the whole Strategic Plan but are, in particular, the central elements of the Territorial and Landscape Plan, which includes the definition of a regional and local Green Infrastructure; of the Natural Environment Plan, which identifies the existing and potential plant communities and establishes the conditions for their adequate improvement and maintenance, and, finally, the Sustainable Development Plan, that analyzes the present flows of energy and resources and explores the territorial and urban models which would permit the reinforcement of internal metabolisms and the reduction of ecological footprints.
\end{abstract}

Keywords: sustainable planning, sustainable development, sustainable metabolisms, green infrastructure, management of natural areas, ecological footprint, ecological planning, public use of natural areas, productive use of natural areas, biodiversity. 


\section{Introduction}

The Calderona Mountain Range is a protected natural park [1, 2] located at the northern border of the Metropolitan Area of Valencia. Its mountainous landform and its deep valleys have historically housed a system of small villages and a deeply interwoven mosaic of traditional Mediterranean crops and forested areas. However, its closeness to the city of Valencia has created in the last decades a strong pressure for public use and for urbanisation, with an increasing constellation of mono-functional new housing states scattered across the whole territory. Likewise, traditional agriculture is receding whilst new irrigated monospecific crops and natural areas gain or recover new land.

It is precisely at this point where the Strategic Territorial Plan for the Calderona Mountain Range [3, 4] tries to define a new scenario based on the improvement and extension of natural ecosystems and on the creation of a more sustainable and harmonic relationship between the urban, agricultural and natural lands.

\section{Analysis and diagnosis}

\subsection{Natural environment}

The natural areas of the Calderona Mountain Range, include a wide variety of ecosystems and plant associations, ranging from water related communities located at the shores of small rivulets and creeks, to termomediterranean edaphoclimatic communities covering wide extensions of uncultivated or non-urbanized land. The acidic quality of most of the soils and the strong contrast between the northern and southern sides of the mountains, increase even more the ecological potential of the site.

Fires and human intervention have reduced however the presence of the mature climax cork oak (Quercus suber) forest to the more internal areas of the mountain range, whilst other less developed stages of the ecological succession cover most of the natural land. These intermediate stages are formed basically by shrubs (Cistus ssps, Quercus coccifera, Pistacia lentiscus, Rosmarinus officinalis, Ulex parviflorus, etc.) which can be also accompanied by a tree layer of pines (Pinus halepensis and pinus pinaster), fig. 1 .

Additionally, the analysis of the Calderona's natural environment included the identification and quantification of existing economic activities (cork harvesting, forestry, biomass production, hunting and apiculture); the evaluation of the existing fire prevention systems and, finally, a diagnosis of the levels and facilities for the public use of the natural park. All this information was collected in different tables and maps which showed an almost inexistent economic activity except for hunting, a lack of continuity and legibility in the network of tracks and a low level of implementation of the Fire Protection Plan [5]. The analysis also showed an increasing detachment and disaffection of local communities, which are somehow losing their personal and functional relationship with their natural sites. 


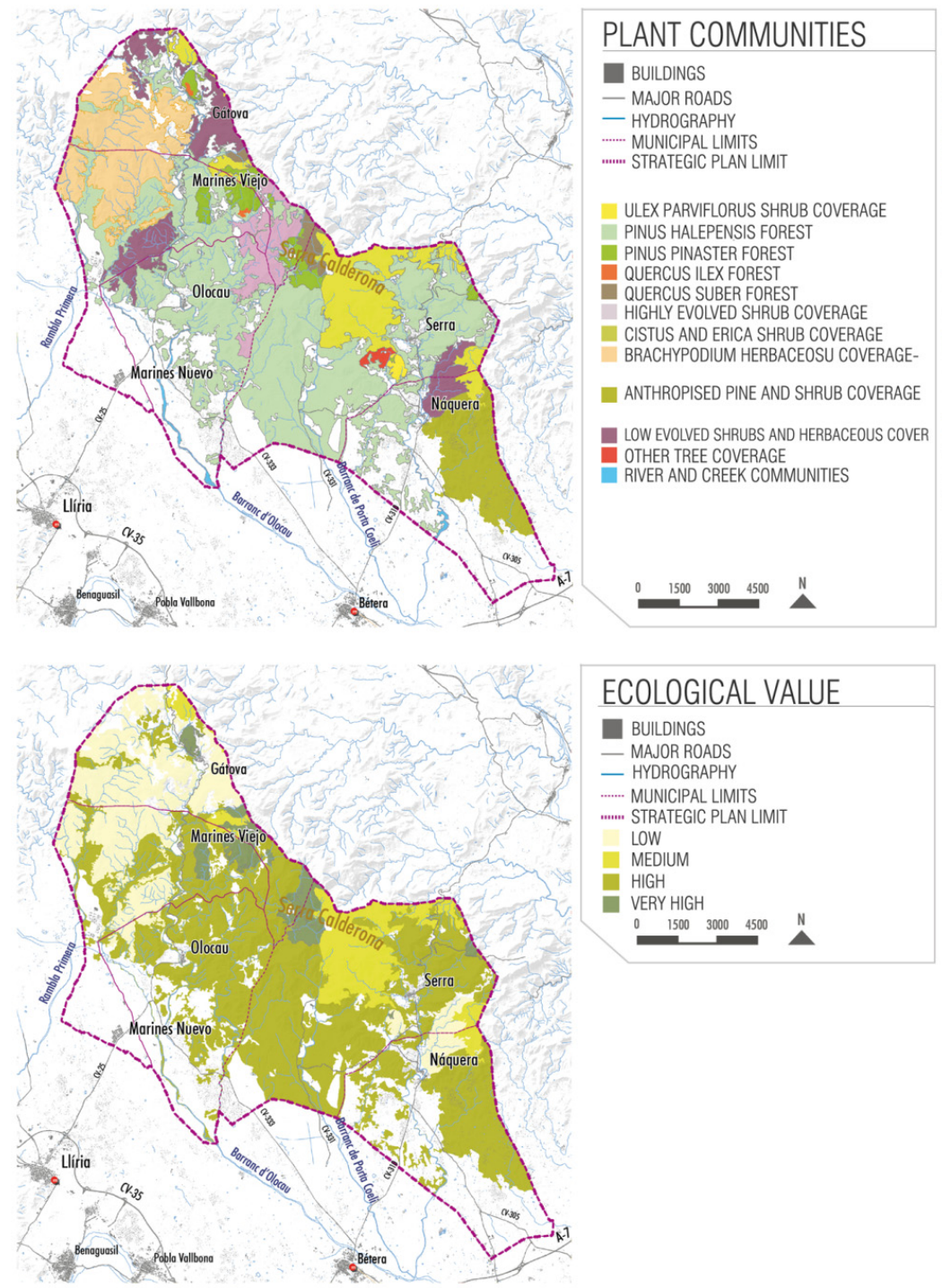

Figure 1: Existing plant communities (as per PATFOR [6]) and ecological value.

\subsection{Landscape and land uses}

The study of the different land uses and landscapes coexisting at the Calderona Mountain Range, shows a fast and intense transformation during the last decades. Somehow, the mosaic is changing, land specialisation is increasing and local communities try to redefine their relationship with a territory which has become protected and which seems to responds now to regional interests and demands. 
The speed of those changes has made difficult their absorption in the landscape and the lack of functional relationship between neighbouring land uses promote a fragmented territory. All these aspects were analysed in a systematic way and were transferred to a set of maps or schemes showing the expected scenarios for the future and the current landscape quality of natural, agricultural, infrastructural and urban areas, fig. 2.

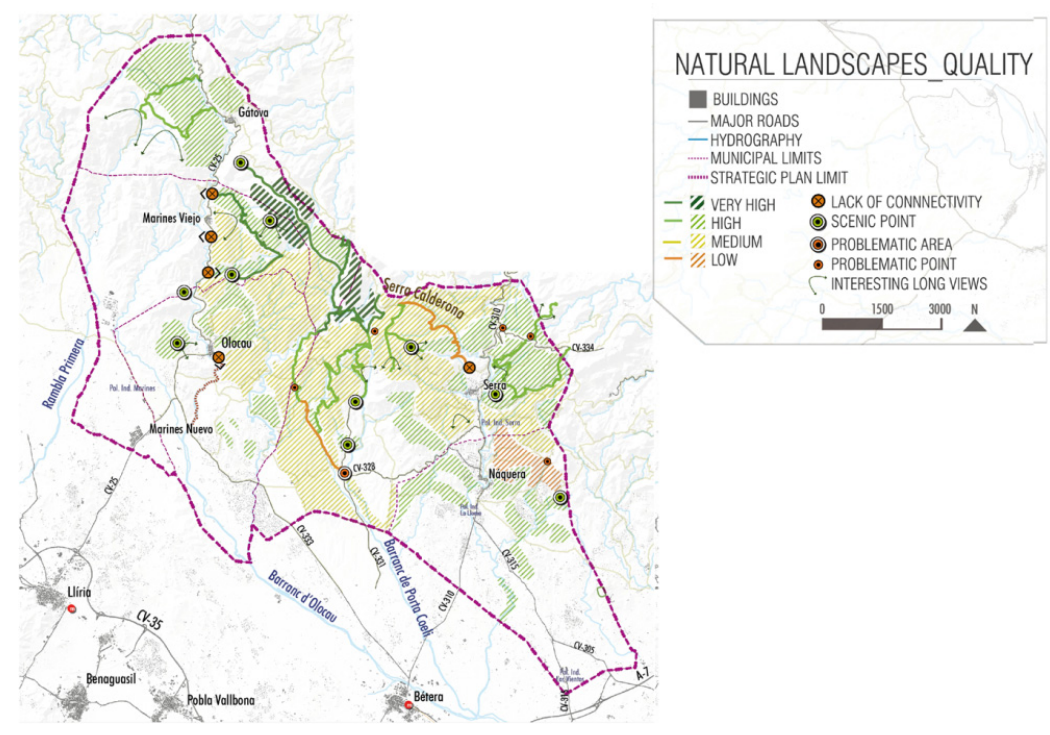

Figure 2: Landscape quality in natural and urban areas.

\subsection{Sustainability}

The harmonic integration of socioeconomic development and the preservation and improvement of natural and cultural heritage is one of the basic pillars of sustainable development. This principle was used in the whole Strategic Plan for the Calderona Mountain Range to analyze some variables like mobility, urban patterns or forestry but, at the same time, required the identification of some objective indicators to assess and develop new alternatives to the current ecological footprints and to the present use of water, energy, resources and residues.

In relation to water, the analysis showed that agriculture and urban-domestic use take the biggest shares in water consumption, fig. 3, presenting both of them a strong seasonality, that in the second case can be explained by the triplication of the population during the summer. Additionally, low density housing is clearly related to higher consumptions per residential unit. On the other end of the water cycle, sewage collection and treatment has improved considerably during the last decades but there are still some extensive housing states lacking sewage networks, what can become a serious environmental problem, especially when they are located over vulnerable aquifers. 


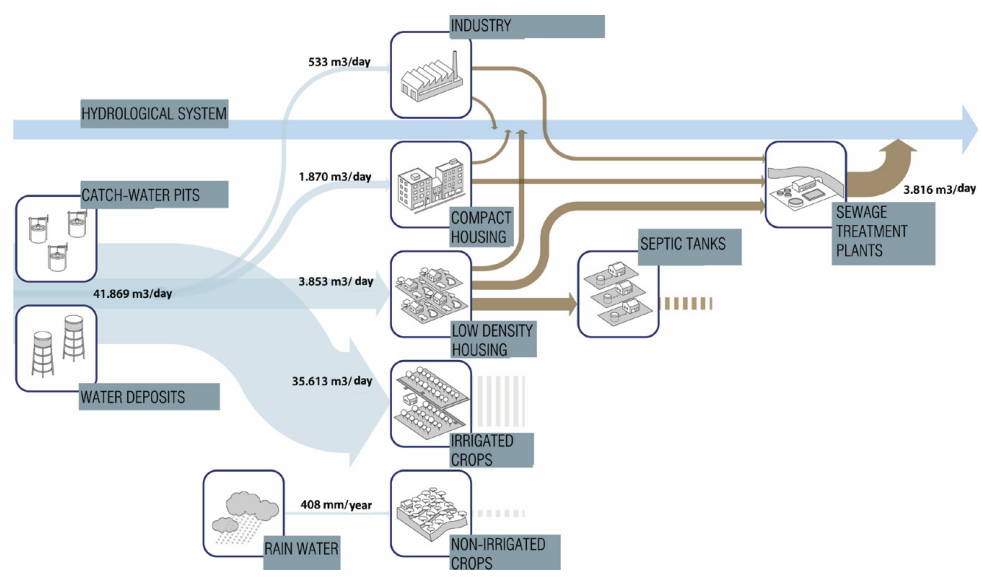

Figure 3: Water cycles. Estimated water consumption and sewage production in high season (summer).

In regards to energy consumption it can be said that this variable is being negatively affected by the predominant use of private transport and by the increasing presence of detached low density housing. This variable also presents a remarkable seasonal pattern and although production of renewable energies is still in an embryonic stage, some interesting projects have been developed to produce energy from biomass.

Finally and in relation to residues, the maintenance of natural and agricultural areas, together with the keeping of the many existing private gardens, produce a remarkable volume of biomass that can be enlarged by importing this material from neighbouring areas and that can be used for energy production. On the other hand, domestic waste can also be partially used in energy production but is also influenced by the strong seasonality of human presence and, although recollection and separation of domestic waste is properly developed, the summer peaks cause some logistic inefficiencies.

As displayed in table 1, all these factors were integrated in the calculation of the ecological footprint for different personal profiles. The results show how this variable is highly related with the degree of compactness and multi-functionality of the different types of urban fabrics and with the way of living that they induce in the people who live in them.

\section{Objectives and strategies}

\subsection{Natural environment}

The list of objectives included the integration of economic activities in forest management practices; diversification and improvement of public use facilities and activities; coordination of fire protection policies with forest management and agro-rural activities (low impact agriculture and extensive shepherding) and, 
Table 1: Ecological footprint for different human profiles.

\begin{tabular}{|c|c|c|c|c|c|c|}
\hline & $\begin{array}{l}\text { Carbon } \\
\text { footprint }\end{array}$ & $\begin{array}{c}\text { Food } \\
\text { footprint }\end{array}$ & $\begin{array}{l}\text { Housing } \\
\text { footprint }\end{array}$ & $\begin{array}{l}\text { Goods and } \\
\text { services } \\
\text { footprint }\end{array}$ & $\begin{array}{c}\text { Total } \\
\text { footprint } \\
\text { per } \\
\text { consumer }\end{array}$ & $\begin{array}{c}\text { Required } \\
\text { planets }\end{array}$ \\
\hline Mean (Calderona area) & 9.85 & 15.35 & 4.31 & 8.83 & 38.33 & 2.44 \\
\hline $\begin{array}{l}\text { Person living in a compact } \\
\text { town and working in a close } \\
\text { industrial state }\end{array}$ & 4.90 & 16.50 & 3.60 & 7.50 & 32.62 & 2.08 \\
\hline Housewife in compact town & 5.70 & 14.90 & 3.60 & 7.50 & 31.75 & 2.02 \\
\hline $\begin{array}{l}\text { Person living in a low } \\
\text { density housing state and } \\
\text { working in the city of } \\
\text { Valencia }\end{array}$ & 17.10 & 19.50 & 4.50 & 10.60 & 51.73 & 3.29 \\
\hline $\begin{array}{l}\text { Part time farmer working } \\
\text { also in the local service } \\
\text { sector }\end{array}$ & 5.70 & 16.50 & 6.10 & 12.70 & 40.92 & 2.60 \\
\hline $\begin{array}{l}\text { Retired person living in a } \\
\text { compact town }\end{array}$ & 4.90 & 12.40 & 3.20 & 6.60 & 27.03 & 1.72 \\
\hline $\begin{array}{l}\text { Retired person living in a } \\
\text { low density housing state }\end{array}$ & 15.20 & 17.00 & 6.50 & 9.10 & 47.73 & 3.04 \\
\hline $\begin{array}{l}\text { Child living in a compact } \\
\text { town }\end{array}$ & 5.70 & 16.50 & 2.40 & 11.60 & 36.22 & 2.31 \\
\hline $\begin{array}{l}\text { Child living in a low } \\
\text { density housing state }\end{array}$ & 17.40 & 19.50 & 7.40 & 12.00 & 56.24 & 3.58 \\
\hline $\begin{array}{l}\text { University student living in } \\
\text { a compact town }\end{array}$ & 9.00 & 16.50 & 3.60 & 7.50 & 36.59 & 2.33 \\
\hline $\begin{array}{l}\text { Temporary resident (in } \\
\text { summer) }\end{array}$ & 22.80 & 19.50 & 6.50 & 12.00 & 60.82 & 3.87 \\
\hline Mean (Spain) & 12.90 & 14.90 & 4.80 & 9.40 & 42.00 & 2.50 \\
\hline
\end{tabular}

finally, promotion of the highest and most bio diverse stages of ecological succession (mature forests), see fig. 4. All these objectives are partially included in the existing management plans of the Calderona Natural Park [1, 2] but have hardly been implemented.

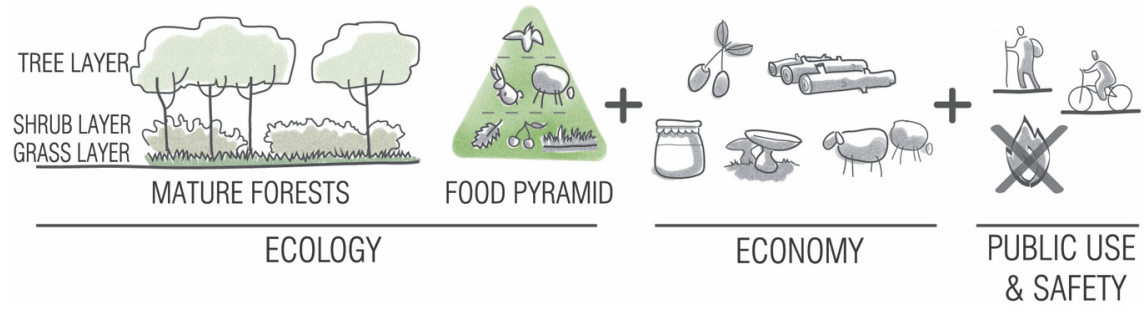

Figure 4: Towards a multifunctional and sustainable use of natural areas. 


\subsection{Landscape and land uses}

The definition of a regional green infrastructure is perceived as the main tool to manage and improve the present evolution of land uses and to put in relation the specific objectives for agricultural, natural, infrastructural and urban lands. This green infrastructure would include and connect strategic areas in the before mentioned lands and would also permit a global improvement in landscape quality. The objectives were all accompanied of a series of strategies for their implementation and are specially detailed for urban and infrastructural environments.

\subsection{Sustainability}

Objectives on sustainability included optimization of water consumption and sewage management; reduction of waste production and increase of recycling; reduction of energy consumption and promotion of renewable energies; enhancement of internal and multifunctional metabolisms, and, finally, the creation of some interactive systems to promote more sustainable ways of living. All these broad objectives were accompanied of specific strategies specially developed for the particular conditions of the Calderona Mountain Range.

\section{Thematic plans}

\subsection{Natural environment plan}

This Plan defines the conditions, agents and programs for the improvement and management of the natural areas of the Calderona Mountain Range.

Firstly, and in order to recover and reinforce the links of local communities with the, now protected, natural environment, the Plan explores and quantifies the economical activities which could be developed in those areas without affecting their environmental quality. As explained in the Plan [3], these activities would also have a small but socially important contribution in local economies and in local employment, playing at the same time a significant role in forest management and fire prevention.

Secondly, the Plan addresses the public use of natural areas by proposing a new zoning based in intensities of public use. This zoning would permit to organise the system of public tracks and would help to preserve the most valuable natural reserves, fig. 6 .

Fire Prevention constitutes the third part of the Natural Environment Plan and, starting from the existing Fire Protection Plan [5], it explores how shepherding and extensive agriculture can become useful and culturally valuable actors on it.

Finally, the fourth part of the Plan deals with Forest Management. This subject is particularly crucial since, traditionally; there have been confronted positions on this issue: those in favour of more intense interventions (strong clearing and thinning) and those who support the spontaneous evolution of the forests. At this point the Strategic Plan for the Calderona Mountain Range advocates for differentiated policies and degrees of management depending on the fire risks, 
intensifying the clearings on vulnerable areas and in forest or agricultural fire breaks and keeping a relatively low level of maintenance in the natural matrix, fig. 5 .

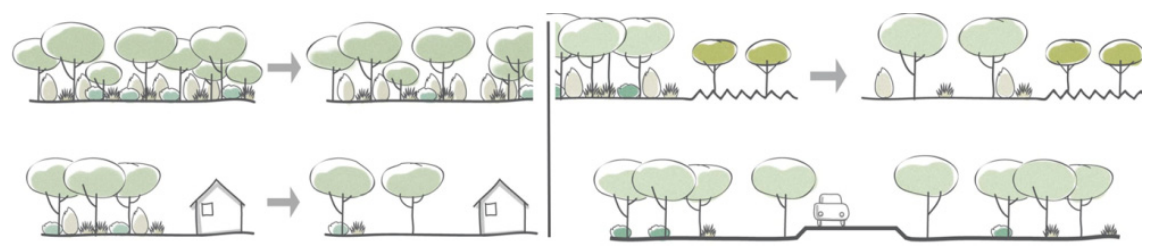

Figure 5: Degrees of intervention and management in different natural areas.

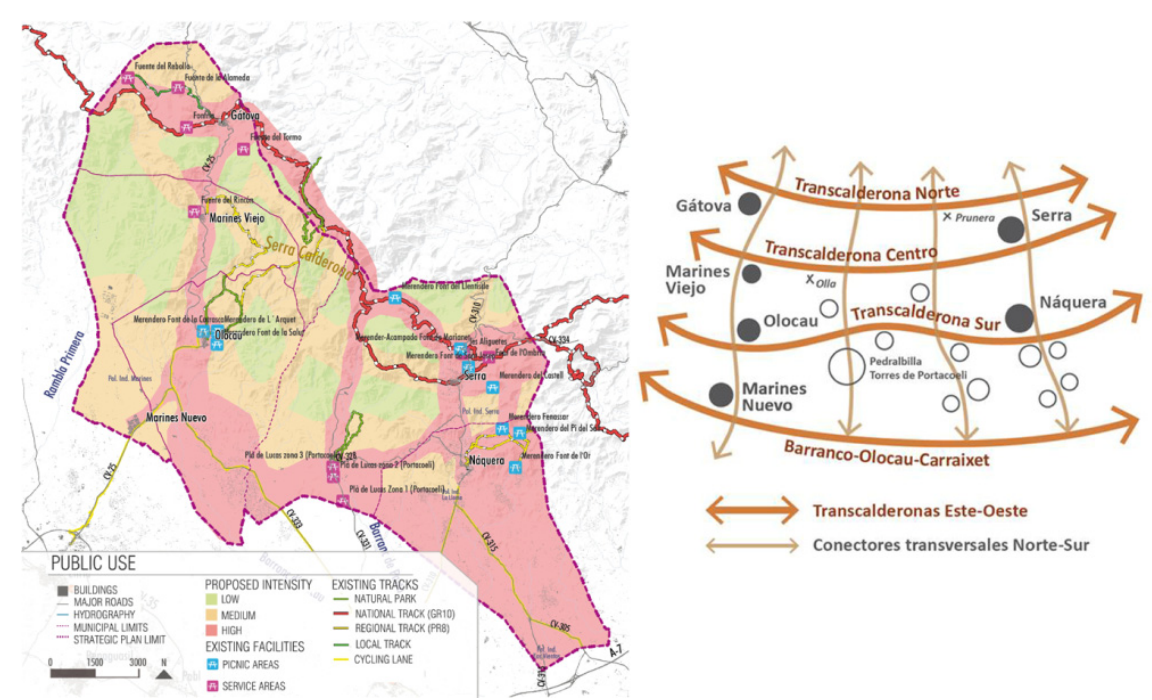

Figure 6: Proposed public use intensity map and conceptual structure for the network of natural tracks.

At a social level, the effects of these maintenance works on local economies and employments were both quantified and the participation of local administrations and outdoor related associations (hikers, climbers, hunters, etc.) was extended or reinforced.

\subsection{Territorial and landscape plan}

The Territorial and Landscape Plan was developed attending the principles of the European Landscape Convention and of the Valencian Planning System [7]. It considers a wide range of environmental, visual, cultural, and economic factors in 
order to optimise the location and intensity of each land use, guaranteeing at the same time the ecological and visual quality of the Calderona Mountain Range.

The Plan was structured in four main parts. The first one included the territorial and landscape characterization of the whole area (definition of landscape units as homogeneous entities with similar patterns and dynamics). In the second part, the quality and degree of visibility of the aforesaid landscape units and of their visual, environmental and cultural resources were estimated. Territorial and Landscape Objectives were formulated on the third part, preparing the floor for the fourth and last part which included the definition of a regional Green Infrastructure and a set of landscape programmes and regulations. Due to the fragmented character of the urban land, a more coherent and functional system of urban management areas was also defined in this last part.

As explained before, the proposed green infrastructure is a central element of the Territorial and Landscape Plan. Ecology has been an essential factor in its definition since it is expected to integrate, enhance and protect the wide diversity of existing ecosystems. This ecological function should not only be performed in natural or agricultural areas but also in the urban context, where the green infrastructure, by incorporating periurban and internal open spaces, is expected to create a capillary and highly accessible subsystem, fig. 7.

Some of the most significant ideas of the Territorial and Landscape Plan were further developed in four pilot projects. The first of them was aimed at facilitating a more adequate and diverse public use of the natural areas by redefining the network of tracks and routes at the Calderona Mountain Range. The second and third pilot projects were pre-designing two periurban parks in the villages of Naquera and Olocau, both of them were located in river areas and were taking advantage of the ecological potential of the sites and of their agricultural surroundings. Finally the fourth project was focused in the visual improvement of a poorly integrated road.

\subsection{Sustainable development plan}

The Sustainable Development Plan addresses two interrelated topics: socioeconomic development and sustainability. In relation to socioeconomic development, it gathers the determinations and proposals of the Agriculture, Forestry, Hunting, Tourist and Urban Plans, defining also the shared programs and structures which should facilitate their progressive implementation. The same applies to sustainability, where the Sustainable Development Plan incorporates the determinations of the before mentioned thematic plans with special attention to water, residues, energy, mobility, urban models and ways of living. In a second part, the Sustainable Development Plan drafts the following three programs that should permit their implementation: sustainable mobility, promotion of endogenous cycles (internal metabolisms) and monitoring of ecological footprints and sustainability levels. As in the other thematic Plans, a set of pilot projects exemplifying the application of the Plan were developed, dealing in this case with the following two topics: Promotion of public transport and Improvement of endogenous cycles for natural resources and labour, fig. 8 . 

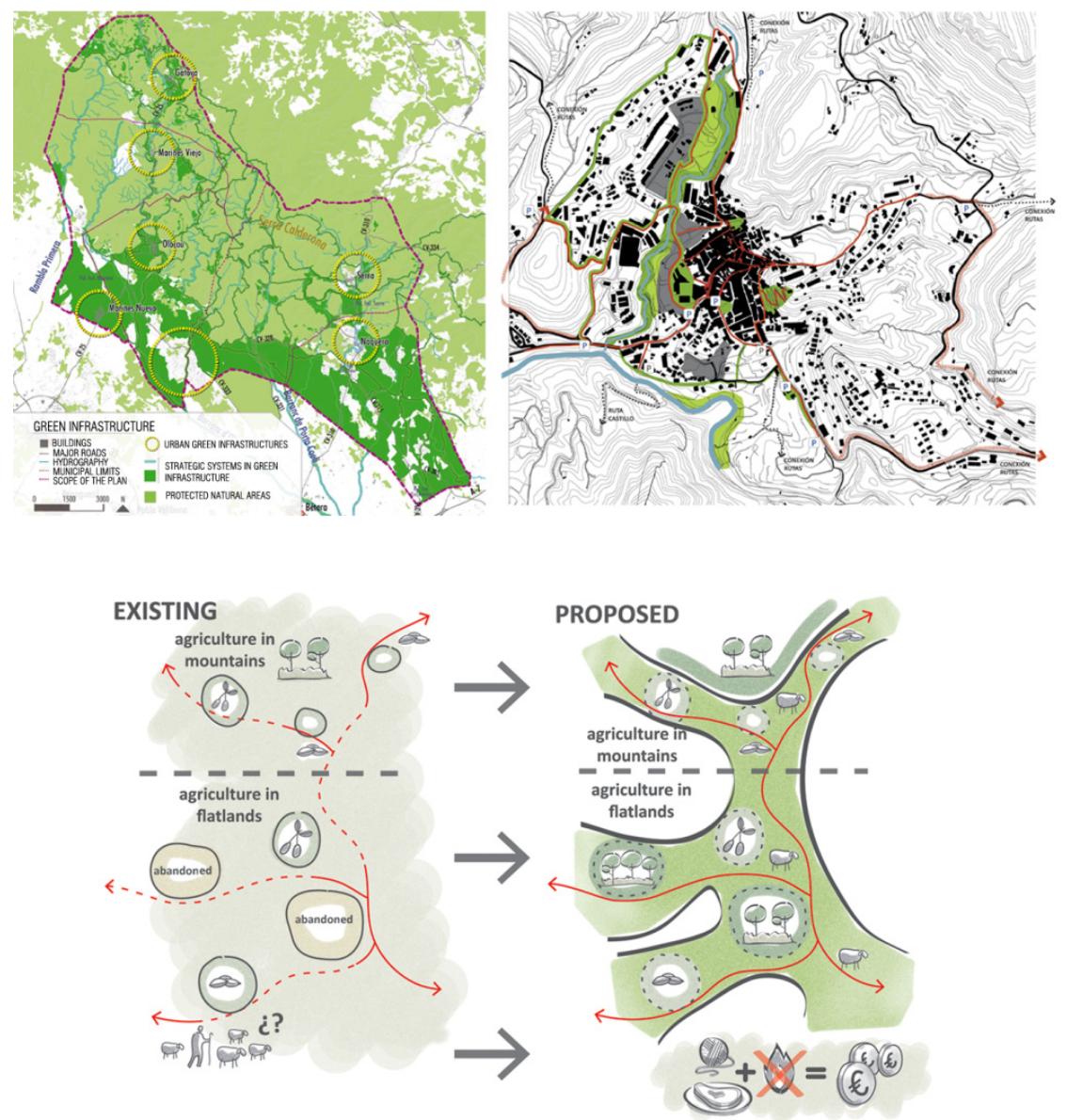

Figure 7: Regional and urban green infrastructures. Towards an agro-naturalurban integrated system.

\section{Conclusions}

Ecology and Sustainability can become structural and essential topics in Planning, guiding the evolution and transformation of both natural and anthropised areas. The Strategic Territorial Plan for the Calderona Mountain Range is guided by this principle and shows how ecology can become a proactive tool to improve the quality, biodiversity and sustainability of our cities, villages and rural areas. Likewise, the Strategic Plan assumes that sustainability should permeate al the layers of planning since only by creating sustainable pieces we can construct sustainable territories. In addition to this, the very same use of the concept of "metabolism" facilitates the required holistic point of view, whilst the introduction of indicators help us be more aware of how we, as individuals or collectives, can perform more sustainable ways of living. 


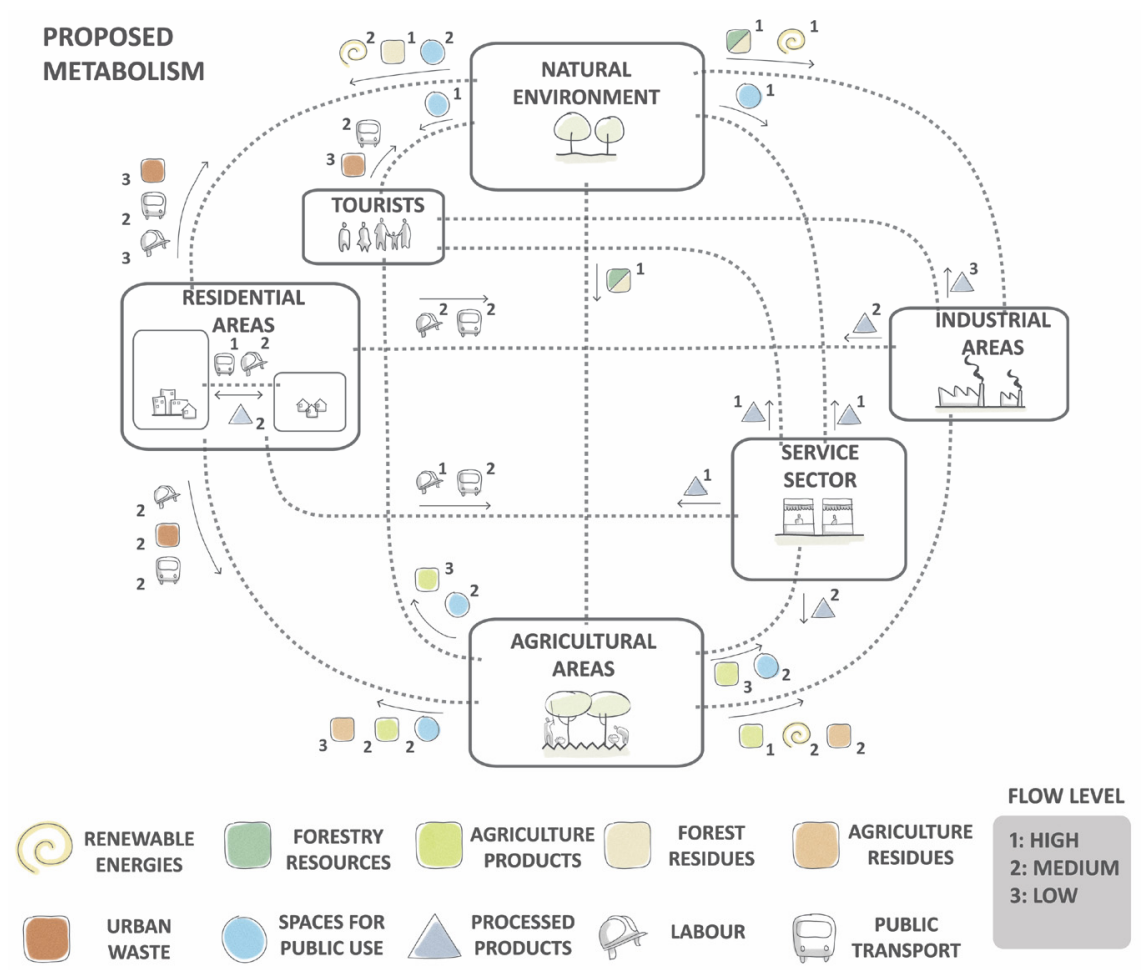

Figure 8: Improvement of regional sustainability. Towards endogenous metabolisms and cycles.

\section{References}

[1] Use and Management Governing Plan for the Calderona Natural Park (Plan Rector de Uso y Gestión del Parque Natural de la Sierra Calderona), Generalitat Valenciana, 2006.

[2] Natural Resources Management Plan for the Calderona Mountain Range (Plan de Ordenación de los Recursos Naturales de la Sierra Calderona); Generalitat Valenciana, 2001.

[3] Galan, J.J., Strategic Territorial Plan for the central area of the Calderona Mountain Range (Plan Territorial Estratégico para el área centro sur de la Sierra Calderona), Ed. Universitat Politecnica de Valencia: Valencia, 2014.

[4] Website of the Strategic Territorial Plan for the central area of the Calderona Mountain Range, www.tusierracalderona.es.

[5] Fire Prevention Plan for the Calderona Natural park (Plan de Prevención de Incendios Forestales en el Parque Natural de la Sierra Calderona); Generalitat Valenciana, 2006. 
262 Ecosystems and Sustainable Development X

[6] Forestry Strategic Action Plan for the Valencian Autonomous Region (Plan de Acción Territorial Forestal de la Comunidad Valenciana, PATFOR), Generalitat Valenciana, 2013.

[7] Strategic Landscape Plans: Methodology \& Regulations for the Valencian Autonomous Region (Reglamento de Paisaje de la Comunidad Valenciana), Generalitat Valenciana, 2004. 